\title{
A STUDY OF THE ACTIVE TECTONICS AND DEFORMATION IN THE MYGDONIA BASIN (N.GREECE) USING SEISMOLOGICAL AND NEOTECTONIC DATA C.B. PAPAZACHOS ${ }^{1}$, D.A. VAMVAKARIS ${ }^{1}$, G.N. VARGEMEZIS ${ }^{1}$ AND E.V. AIDONA ${ }^{1}$
}

\section{ABSTRACT}

In the present work we study the active tectonics setting and related deformation scheme in the Mygdonia basin, on the basis of the joint interpretation of seismological and neotectonic data. For this reason, the stress field derived from fault plane solutions of small-magnitude events from a local seismological experiment, as well as neotectonic observations are studied in order to determine its spatial distribution. The results show an almost identical spatial variation of the stress field determined from the two independent data sets, which also exhibits a very good correlation with the geomorphological changes in the Mygdonia basin. Moreover, the average stress field is almost identical to the corresponding stress pattern determined from the 3 largest events in the study area for which reliable fault plane solutions are available. Using the combined stress pattern and the corresponding moment-rate tensors derived from both data sets, the active crustal deformation is studied for the most active sections of the Mygdonia basin system. The results show a N-S extension at an average rate of $3 \mathrm{~mm} /$ yr for the central part of the Mygdonia system, in very good agreement with the available geodetic results.

KEY WORDS: Stress field, active deformation, strain tensor, Mygdonia basin

\section{THE MYGDONIA BASIN AREA}

The Mygdonia basin is one of the most active seismogenic regions in the back-arc Aegean area. The basin is located at the centre of the Servomacedonian massif, which is surrounded by a series of basins/troughs, namely the Axios and Strymon basins and the North Aegean Trough (fig.1). The seismicity of the Servomacedonian

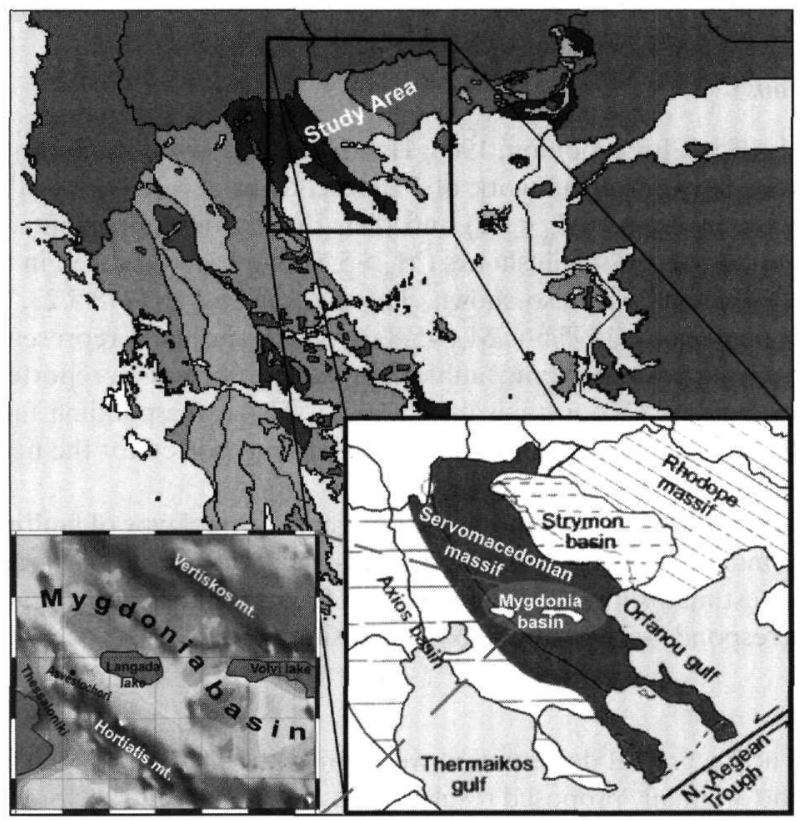

Fig. 1. Map of the main geological zones of Greece. The inset figures show the detailed geomorphological features of the Mygdonia basin.

1. Dept. of Geophysics, School of Geology, Aristotle University of Thessaloniki, PO Box 352-1, Thessaloniki, GR-54006, GREECE 
massif which extends from the Yugoslavia-Bulgaria border up to the North Aegean Trough is the highest in N. Greece with events up to $M_{w}=7.6$ (Papazachos et al., 1979). A large portion of this seismic activity is located in the Mygdonia basin and its continuation towards the Ierissos bay area. The basin has a characteristic S-shape (see fig. 1) with its edges trending in a NW-SE direction, while the central part is approximately E-W oriented. This central section is the most seismically active and has received a lot of scientific attention, since the occurrence of the $M_{w}=6.5$ mainshock of June 20,1978, which was the first major event with significance impact on a modern urban centre like the city of Thessaloniki (Papazachos et al., 1979; Pavlides and Kilias, 1987; Pavlides et al., 1988; Hatzidimitriou et al., 1991).

\section{DATA USED}

The data used consist of three different datasets. The first data set corresponds to the fault plane solutions determined from the analysis of earthquakes recorded by a local network which operated in the Mygdonia area

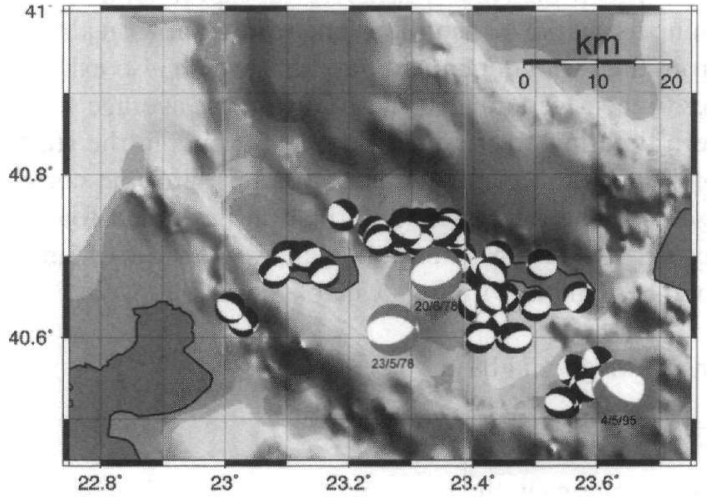

Fig. 2. Fault plane solutions determined for 63 small earthquakes recorded in the spring of 1984 and 1985 (black solutions). The solutions of the 3 main earthquakes $\left(M_{W}>5.5\right)$ are also shown (grey solutions).

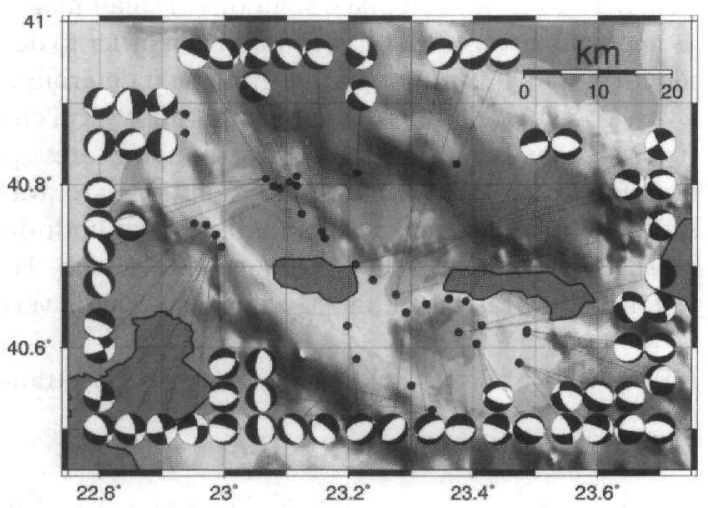

Fig. 3. Fault plane solutions corresponding to the neotectonic faults of the broader Mygdonia basin (see text for explanations).

in the springs of 1984 and 1985 (Christodoulou, 1986; Hatzfeld et al., 1987). Additional fault plane solutions for the Asvestochori area were used from the work of Papazachos et al. (2000). All these fault plane solutions correspond to small magnitude events $\left(\mathrm{M}_{\mathrm{w}} \leq 3.1\right)$ and their distribution is presented in figure 2 . In the same figure, the fault plane solutions of the 3 mainshocks $\left(M_{w}>5.5\right)$ that have occurred in the area for which reliable fault plane solutions were available are also shown. These mainshocks $\left(1978 / 5 / 23, \mathrm{M}_{\mathrm{w}}=5.8\right.$, Volvi preshock; $1978 / 6 / 20, M_{w}=6.5$, Volvi mainshock; $1995 / 5 / 4, M_{w}=5.8$, Arnaia mainshock) represent the second dataset used. The last dataset corresponds to the neotectonic faults and related information reported in the neotectonic maps of "Langadas" and "Thessaloniki" (Mountrakis et al., 1997). The corresponding fault plane solutions, which were determined using the fault plane and slip vector information reported for the neotectonic faults are shown in figure 3 .

Both the seismological and neotectonic data show a dominant normal type of faulting for the whole Mygdonia basin area. Although the small-magnitude events and small-scale faults exhibit a variety of fault azimuths, most events, as well as the 3 largest mainshocks show an average E-W fault direction, in agreement with the general basin lineation, which corresponds to an average N-S extension field.

\section{APPLIED METHOD}

In order to study the active crustal deformation we applied the method of Papazachos and Kiratzi (1992). The method is based on the originally proposed results of Kostrov (1974) and Jackson and McKenzie (1988) and relies on the use of all complete seismicity data for the estimation of the size of the deformation and all the available fault plane solutions, which do not need to be complete for the examined time period. Using this approach, which has been applied in several cases in Greece (e.g. Papazachos et al., 1992; Papazachos and Kiratzi, 1996) the problem of complete fault plane solution data can be overcome using information derived 
from other sources. Such sources are the historical seismicity for the estimation of the deformation rate or field active-faults observations for the determination of the deformation pattern.

For the estimation of the strain rate tensor, $\dot{\varepsilon}_{\mathrm{ij}}$, and the velocity tensor, $\mathrm{U}_{\mathrm{ij}}$, the following equations are used (Papazachos and Kiratzi, 1992):

$$
\begin{gathered}
\dot{\varepsilon}_{\mathrm{ij}}=\frac{1}{2 \mu \mathrm{V}} \dot{\mathrm{M}}_{\mathrm{o}} \cdot \overline{\mathrm{F}}_{\mathrm{ij}} \quad \mathrm{i}, \mathrm{j}=1,2,3 \quad \mathrm{U}_{\mathrm{ii}}=\frac{1}{2 \mu \mathrm{l}_{\mathrm{k}} \mathrm{l}_{\mathrm{j}}} \dot{\mathrm{M}}_{\mathrm{o}} \cdot \mathrm{F}_{\mathrm{ii}} \quad \mathrm{i} \neq \mathrm{k}, \mathrm{k} \neq \mathrm{j}, \mathrm{j} \neq \mathrm{i}, \mathrm{i}=1,2,3 \\
\mathrm{U}_{12}=\frac{1}{\mu \mathrm{l}_{1} \mathrm{l}_{2}} \dot{\mathrm{M}}_{\mathrm{o}} \cdot \overline{\mathrm{F}}_{12} \quad \mathrm{U}_{\mathrm{i} 3}=\frac{1}{\mu \mathrm{l}_{\mathrm{l}} \mathrm{l}_{3}} \dot{\mathrm{M}}_{\mathrm{o}} \cdot \mathrm{F}_{\mathrm{i} 3} \quad \mathrm{i}=1,2
\end{gathered}
$$

where $\mathrm{l}_{1}, \mathrm{l}_{2}, \mathrm{l}_{3}$, are the dimensions of the deforming zone, $\mu$ is the shear modulus (usually taken $3.10^{11} \mathrm{dyn} / \mathrm{cm}^{2}$ ) and, $\dot{\mathrm{M}}_{\mathrm{o}}$, is the released moment rate, defined by the seismicity level of the area using the relation of Molnar (1979):

$$
\dot{M}_{0}=\frac{A}{1-B} \bullet M_{0, \max }^{1-B}
$$

where $M_{o \max }$ corresponds to the seismic moment of the maximum-magnitude event in the deforming zone. Constants $A$ and $B$ can be determined using the Gutenberg-Richter parameters of the zone and the constants of the seismic moment-magnitude relation using, appropriate formulas. $F$ is the average "focal mechanism" tensor, which represents the deformation pattern of the area and is the average of the individual $\mathrm{F}^{\mathrm{n}}$ tensors which correspond to each fault plane solution and are a function of the corresponding strike, $\zeta$, dip, $\delta$, and rake, $\lambda$ (Aki and Richards, 1980).

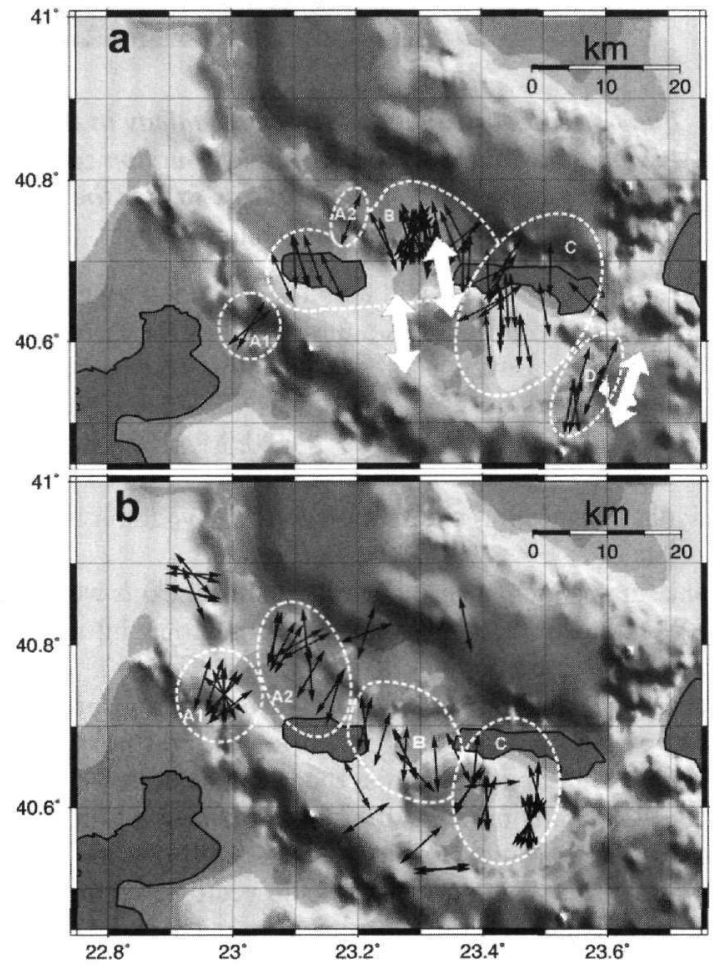

Fig. 4. a) Extensional T-axes for the 63 small earthquakes (black arrows) and the 3 main events with $M>5.5$ (white arrows), grouped in zones with similar tectonic characteristics. a) Same as (a) for the neotectonic data.
As can be seen from equations (1), the estimation of the strain and velocity tensors is decomposed in the estimation of the moment-rate and the representative focal mechanism tensor. For this reason the estimation of the active deformation can be performed in two steps:

a) Areas with similar tectonic characteristics can be grouped in order to define a reliable average "focal mechanism" tensor, using all fault plane data.

b) The moment-rate is estimated using the complete instrumental and historical seismicity through the Gutenberg-Richter relation and equation (2).

\section{IDENTIFICATION OF ZONES OF SIMILAR FAULTING}

In order to define zones of similar tectonic setting, the spatial distribution of the stress axes was studied, as these are defined by the corresponding fault plane solutions. Since the study area is dominated by extension, the zone identification was mainly based on the similarity of the T-axes. Figure 4 a shows the T-axis distribution for the earthquake data, while $4 \mathrm{~b}$ shows the corresponding distribution for the neotectonic data. In general 4 main zones are recognized:

a) Zone $A$. This zone includes the north (A1) and south (A2) borders of NW-SE trending basin segment west of the Langada lake. Both seismological and neotectonic data suggest that a NE-SE tension field dominating these basin borders, although limited seismological data are available. For this reason, as well as due to the very similar T-axis distri- 


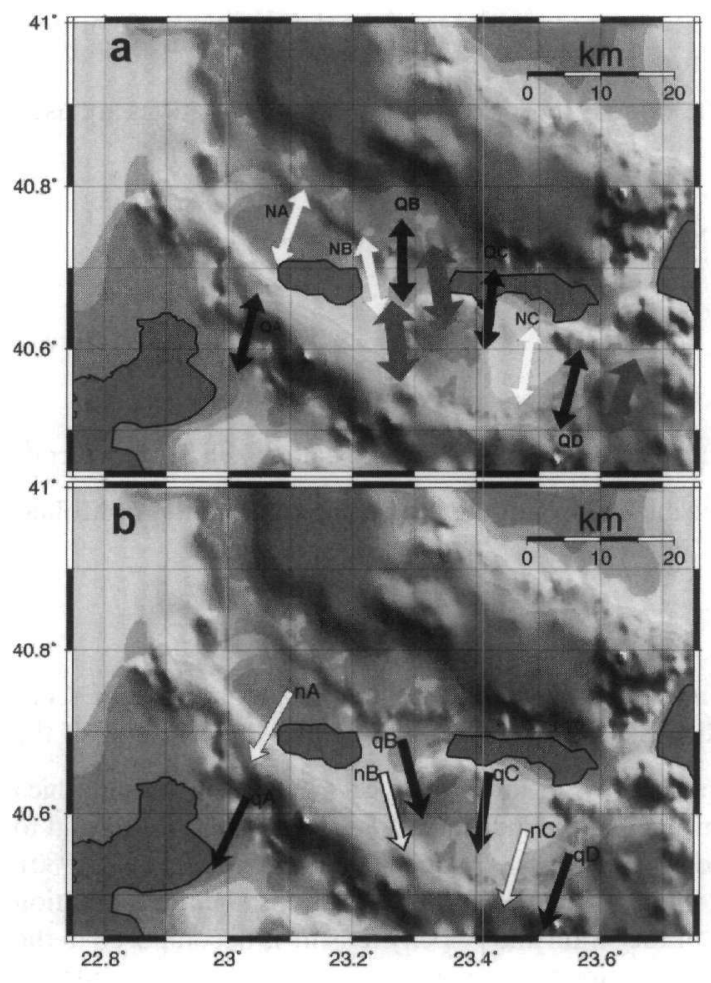

Fig. 5. a) Average extension axes for the small earthquake (black arrows) and the neotectonic (white arrows) data. b) Same as (a) for the average slip vector data.

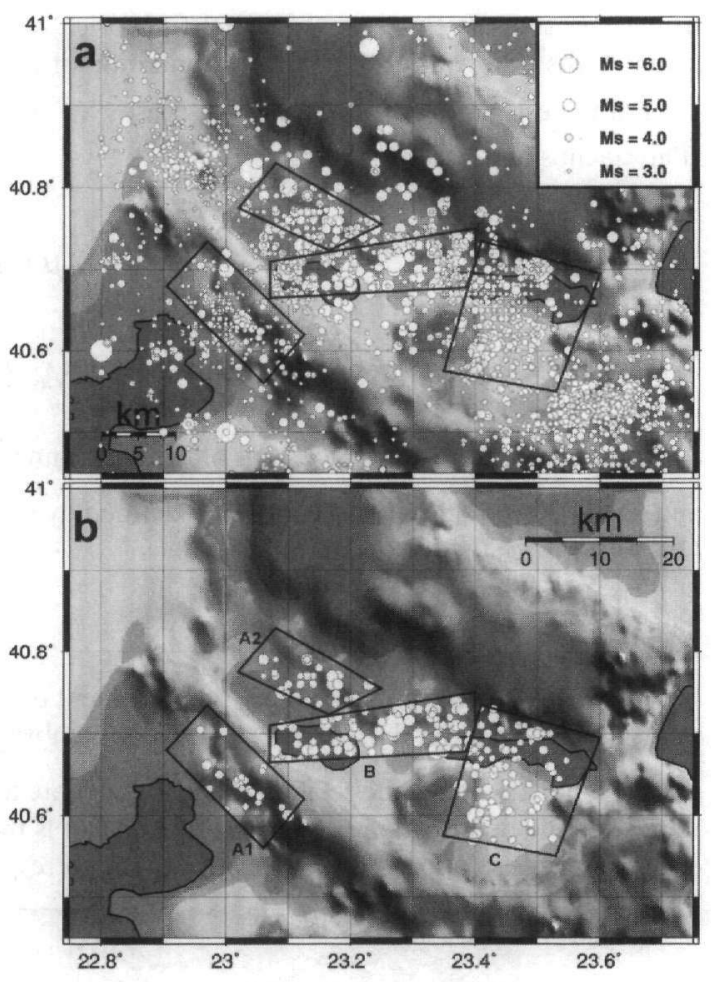

Fig. 6. a) Historical and observed seismicity in the Mygdonia basin area. The studied deformation zones are shown by polygons. b) Same as (a) for the complete seismicity data.

bution, the two sub-zones (A1-A2) are considered to have the same stress field and are examined together.

b) Zone B. This zones corresponds to the central main part of the Mygdonia basin and includes the Langada lake, the central basin parts between the Langada and Volvi lakes, as well as the westernmost section of the Volvi lake. The tension axis of both seismological and neotectonic data shows a N-S to NNE-SSE direction, in agreement with the T-axis of the 1978 Volvi events $\left(1978 / 5 / 23, M_{w}=5.8\right.$ and 1978/6/20, $\left.M_{w}=6.5\right)$, which are also shown with large white arrows.

c) Zone C. The zone includes the largest part of the Volvi lake, as well as the section of the Mygdonia basin south of the Volvi lake, showing a general N-S extension field.

d) Zone D. This is the area of the $1995 / 5 / 4, M_{w}=5.8$, Arnaia mainshock, where both the mainshock as well as the local experiment seismological data show a NNE-SSW extension field, although no neotectonic information were available for this area.

In order to study the behavior of the stress field in each zone, the average "focal mechanism" tensor was estimated for each zone. Figure 5a shows the corresponding extension T-axes defined using the seismological (Q) and neote-ctonic $(\mathrm{N})$ data. In order to compare the relative motion pattern across the various faults, we also present the average slip vectors, which correspond to the southern hanging wall of the fault plane solution.

The results show an almost identical pattern of the stress-field variation for both data sets. For zone A, a identical NNE-SSW extension field $\left(14^{\circ}\right)$ is found for the two data sets, with an average slip vector direction of $207^{\circ}$. However, both the stress field and the slip-vector directions change for the central part (zone B). The extension axis changes to N-S $\left(359^{\circ}\right)$ for the earthquake data and NNW-SSE $\left(348^{\circ}\right)$ for the neotectonic data, whereas the slip-vectors show an identical SSE $\left(165^{\circ}\right)$ direction. The 1978 preshock and mainshock extension axes are in very good agreement with the proposed T-axis direction. Moving eastward, towards the Volvi area, the extension field changes again to N-S/NNE-SSW (7-9 $)$, with a slightly larger azimuth $\left(14^{\circ}\right)$ in the Arnaia area (zone D) as this is deduced from the seismological data. The slip vectors are also modified in a similar manner, showing a SSW directions between $188^{\circ}$ and $199^{\circ}$. 
It is interesting to notice that the stress field and the slip vector variations follow the S-shape of the Mygdonia basin. In every zone, the T-axis and especially the slip-vector are almost perpendi-cular to the basin trend, showing that the geomorpho-logical characteristics are affected but also affect the tectonic regime of the area. Even in areas like zone A, where the stress field is relatively oblique to the basin axis, the basin border faults are still moving away from each other, which suggests that the basin is still under extensive deformation. In the next section we attempt to estimate the deformation rates, using the method previously described.

\section{ESTIMATION OF ACTIVE CRUSTAL DEFORMATION IN THE MYGDONIA BASIN}

Figure 6a shows the observed seismicity (historical and instrumental) for the examined area. It is easily seen that most of the seismic activity in the area is concentrated in the Mygdonia basin. The polygons delineate the main zones which have been previously defined and which contains most of the seismic activity in the area. We have selected not to include the Arnaia area (zone D) in the calculations due to the absence of neotectonic information, few fault plane solutions from earthquakes but mostly since the intense recent aftershock activity after the 1995 event would probably result in an overestimation of the deformation rates.

In order to estimate the deformation rate for each source, it is necessary to use only the complete seismicity data. For the study area, we used the completeness derived for the broader Aegean area from Papazachos and Papazachou (1997), in combination with the results of Scordilis (1985) for the Servomacedonian area. Hence, we considered as complete all $M_{w} \geq 5.0$ events after $1911, M_{w} \geq 4.5$ after $1950, M_{w} \geq 4.3$ after 1965 and $M_{w} \geq 3.0$ after 1981. The corresponding distribution of the complete seismicity for the 4 polygonal areas is shown in figure $6 \mathrm{~b}$, where it is clearly seen that the central part is the most active section of the Mygdonia basin system.

Using the complete seismicity data, the parameters of the Gutenberg-Richter relation were calculated. For the moment-rate estimation it is also necessary to define the maximum expected magnitude for each zone. From the observed seismicity (fig. 6a) the maximum observed event was defined in each polygon. Especially for zone A1, although the maximum observed event was $M=5.5$, the maximum magnitude considered was increased to $M_{w}=6.0$, since both the length of the active neotectonic faults in the area, as well as the possibility that the 1759 event is located in this zone suggest that the seismic potential of the zone can produce an event of such magnitude. The information regarding each zone, as well as the determined maximum magnitude and the GutenbergRichter parameters are shown in Table 1. In the same table the geometric characteristics of each zone (length, width, azimuth) used in equation (1), as well as the annual moment-rate finally estimated using equation (2) are also presented. In all cases, the thickness of the seismogenic layer was considered equal to $10 \mathrm{~km}$.

Table 1. Parameters of the zones for which deformation has been estimated.

\begin{tabular}{|c|c|c|c|c|c|c|c|c|c|c|c|}
\hline \multirow[t]{2}{*}{ ZONE } & \multicolumn{2}{|c|}{ ZONE LIMITS } & \multicolumn{2}{|c|}{ COMPLETENESS } & \multirow{2}{*}{$\begin{array}{l}\text { MAXIMUM } \\
\text { MAGNITUDE } \\
\text { Mw, max }\end{array}$} & \multirow{2}{*}{$\begin{array}{l}\text { LENGTH } \\
\frac{11(\mathrm{~km})}{}\end{array}$} & \multirow{2}{*}{$\begin{array}{l}\text { MDTH } \\
12(\mathrm{~km})\end{array}$} & \multirow{2}{*}{$\frac{\text { AZIMUTH }}{\xi}$} & \multirow{2}{*}{$\begin{array}{l}\text { ANNUAL MOMENT- } \\
\text { RATE } \\
\text { Mo }\end{array}$} & \multicolumn{2}{|c|}{$\begin{array}{l}\text { GUTENBERG-RICHTER } \\
\text { PARAMETERS }\end{array}$} \\
\hline & $\varphi^{\circ} \mathrm{N}$ & $\lambda^{\circ} \mathrm{E}$ & $t$ & Mmin & & & & & & a (Annual) & b \\
\hline A1 & $\begin{array}{l}40.680 \\
40.735 \\
40.620 \\
40560\end{array}$ & $\begin{array}{l}22.905 \\
22.970 \\
23.125 \\
23060\end{array}$ & $\begin{array}{l}1911 \\
1950 \\
1965 \\
1981\end{array}$ & $\begin{array}{l}5.0 \\
4.5 \\
4.3 \\
3.0\end{array}$ & $\begin{array}{l}5.5 \\
6.0\end{array}$ & 20.6 & 9.1 & 134 & $0.297 \mathrm{E}+23$ & 3.36 & 1.05 \\
\hline A2 & $\begin{array}{l}40.775 \\
40.830 \\
40.775 \\
40.723\end{array}$ & \begin{tabular}{|l|}
23.020 \\
23.080 \\
23.250 \\
23.165
\end{tabular} & $\begin{array}{l}1911 \\
1950 \\
1965 \\
1981\end{array}$ & $\begin{array}{l}5.0 \\
4.5 \\
4.3 \\
3.0\end{array}$ & 5.9 & 17 & 7.9 & 115 & $0.558 \mathrm{E}+23$ & 3.58 & 1.03 \\
\hline B & $\begin{array}{l}40.665 \\
40.710 \\
40.750 \\
40.708 \\
40678\end{array}$ & $\begin{array}{l}23.070 \\
23.070 \\
23.400 \\
23.400 \\
23.385\end{array}$ & $\begin{array}{l}1911 \\
1950 \\
1965 \\
1981\end{array}$ & $\begin{array}{l}5.0 \\
4.5 \\
4.3 \\
3.0\end{array}$ & 6.6 & 30.9 & 7.9 & $\overline{84}$ & $0.598 \mathrm{E}+24$ & 3.47 & 0.89 \\
\hline C & $\begin{array}{l}40.735 \\
40.695 \\
40.550 \\
40.575\end{array}$ & \begin{tabular}{|l|}
23.410 \\
23.600 \\
23.530 \\
23.350
\end{tabular} & $\begin{array}{l}1911 \\
1950 \\
1965 \\
1981\end{array}$ & $\begin{array}{l}5.0 \\
4.5 \\
4.3 \\
3.0\end{array}$ & 6.6 & 17.9 & 20 & 105 & $0.253 E+24$ & 4.02 & 1.05 \\
\hline
\end{tabular}

Using the information in Table (1), we proceeded in the determination of the strain and velocity tensors, by the application of equations (1). For this reason the representative focal mechanism tensor was derived for each zone, using the average tensor from both seismological and neotectonic data. The representative fault plane solutions used for each zone are shown in Table 2. 
Table 2. Average fault plane solutions of the seismological and neotectonic data of each zone, which were used to determine the average "focal mechanism" tensor.

\begin{tabular}{|c|c|c|c|c|}
\hline & ZONE & \multicolumn{3}{c|}{ Main Fault Plane } \\
\hline & Data Type & $\zeta$ & $\delta$ & $\lambda$ \\
\hline \multirow{2}{*}{ A } & qA & 88 & 36 & -112 \\
\cline { 2 - 5 } & nA & 101 & 43 & -102 \\
\hline \multirow{2}{*}{ B } & qB & 104 & 45 & -68 \\
\hline \multirow{2}{*}{$\mathbf{C}$} & nB & 82 & 38 & -84 \\
\cline { 2 - 5 } & qC & 96 & 43 & -90 \\
\hline
\end{tabular}

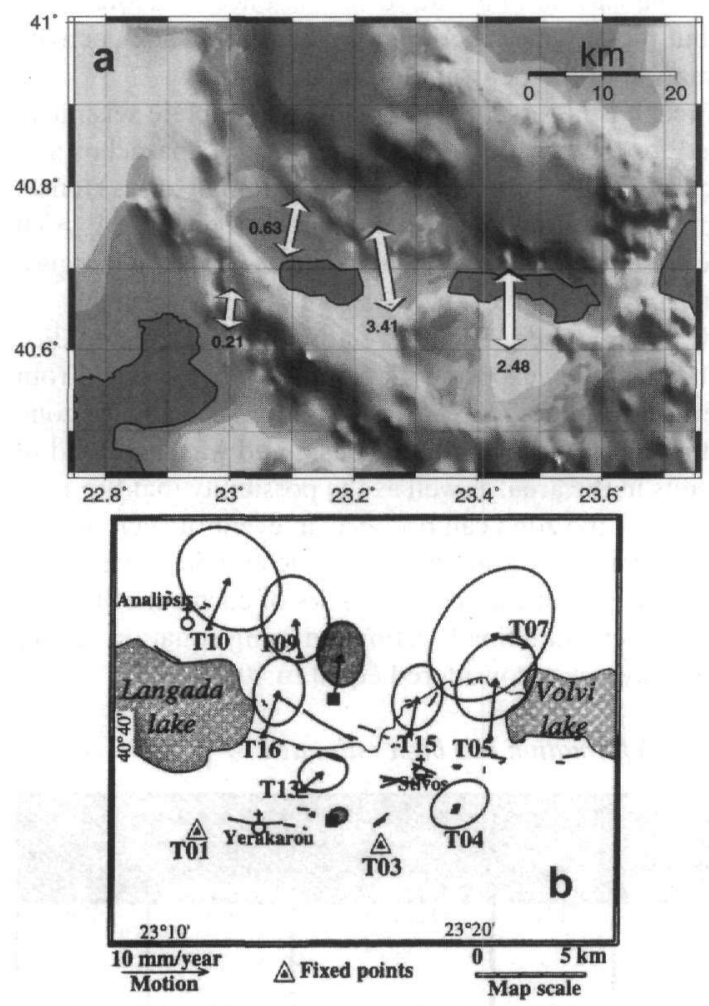

Fig. 7. a) Extensional velocities (in mm/yr) estimated for the studied zones of the Mygdonia basin. $b$ ) Velocities of the northern part of the central section of the Mygdonia basin with respect to its southern border, as determined by the use of geodetic data (Martinod et al., 1997).
Figure 7a shows the horizontal eigenvectors of the velocity tensor determined for each zone using the information presented in Tables 1 and 2. A logarithmic scale is used and the presented velocities are expressed in $\mathrm{mm} / \mathrm{yr}$. The results confirm the N-S extensional deformation pattern of the Mygdonia basin area and are in very good agreement with previous large-scale studies (e.g. Papazachos and Kiratzi, 1996). The deformation direction in each zone corresponds very well with the S-shape of the basin, similarly to the stress T-axis and the slip vectors, previously described. Velocities are much higher for the central part of the basin, between the two lakes of Langada and Volvi $(-3.5 \mathrm{~mm} /$ yr) and relatively high for the broader Volvi area $(\sim 2.5 \mathrm{~mm} / \mathrm{yr})$. On the other hand, the deformation velocities at the borders of the western part of the area (zones A1 and A2) exhibit much lower velocities, which correspond very well with the lower seismicity levels of this area. Moreover, in this area (zone A) the Mygdonia basin has its smallest aperture, which suggests that the identified velocity contrast of a factor of $\sim 4$ between the western and central-eastern part of the Mygdonia basin has probably also occurred during the last phase of the Mygdonia basin formation and is still going on until today. Furthermore, the corresponding near-vertical thinning rates are $0.31 \mathrm{~mm} / \mathrm{yr}$ for zone $\mathrm{A} 1$, $0.81 \mathrm{~mm} / \mathrm{yr}$ for zone A2, $4.6 \mathrm{~mm} / \mathrm{yr}$ for zone B and $1.2 \mathrm{~mm} / \mathrm{yr}$ for zone $\mathrm{C}$. The high thinning rates for the central part are also in agreement with the location of the lowest topographic depression in the central part of the basin between the two lakes.

Figure $7 \mathrm{~b}$ presents the determined velocities using GPS and conventional geodetic data of the northern part of the central section of the Mygdonia basin (corresponding to zone B) with respect to stations T01 and T03, located at the southern flank of the central Mygdonia basin (Martinod et al., 1997). It should be noted that the geodetic data exhibit an almost identical N-S extension pattern for the area. The average determined velocity from the geodetic data for the total extension between 1978 and 1994 is equal to $5.7 \mathrm{~mm} / \mathrm{yr}$. This observation suggests that the seismic (active) crustal deformation is approximately $60 \%$ of the total deformation, which is expressed by the geodetic measurements, in agreement with previous results for the broader Aegean area (Papazachos and Kiratzi, 1996).

\section{ACKNOWLEDGEMENTS}

This work is a Department of Geophysics, Univ. of Thessaloniki contribution number \#552/2001. Part of 
this work has been financed by the Earthquake Planning and Protection Organization of Greece (OASP) through Research Comm. Aristotle Univ. Thessaloniki projects 20237 and 20321.

\section{REFERENCES}

AKI, K. AND RICHARDS, P. 1980. Quantitative Seismology: Theory and methods, Freeman, San Francisco, Calif.,557 pp.

CHRISTODOULOU, A. 1986. Etude Sismotectonique et Inversion Tridimensionnelle en Grece du Nord. PhD thesis, University of Grenoble I, pp. 181.

HATZFELD, D., CHRISTODOUlOU, A.A., SCORDILIS, E.M., PANAGIOTOPOULOS, D., AND P.M. HATZIDIMITRIOU, 1987. A microearthquake study of the Mygdonian graben (northern Greece). Earth and Planetary Science Letters 81, 379-396.

HATZIDIMITRIOU, P.M., SCORDILIS, E.M., PAPADIMITRIOU, E.E., HATZFELD, D. AND CHRISTODOULOU, A.A. 1991. Microearthquake study of the Thessaloniki area (northern Greece). Terra Nova 3, 648-654.

JACKSON, J. AND MCKENZIE, D. 1988. The relationship between plate motions and seismic moment tensors and the rates of active deformation in the Mediterranean and Middle East. Geophys. J. Int. 93, 45-73.

KOSTROV, V. 1974. Seismic moment and energy of earthquakes, and seismic flow of rock. Izv. Acad. Sc. USSR Phys. Solid Earth, 1, 23-44.

MARTINOD, J., HATZFELD, D., SAVVAIDIS, P. AND KATSAMBALOS, K. 1997. Rapid N-S extension in Mygdonian graben (Northern Greece) deduced from repeated geodetic surveys. Geophysical Research Letters 24, 3293-3296.

MOUNTRAKIS, D., KILIAS, A., PAVLIDES, S., SOTIRIADIS, L., PSILOVIKOS, A., ASTARAS, T., VAVLAKIS, E., KOUFOS, G., DIMOPOUlOS, G., SOULIOS, G., XRISTARAS, V., SKORDILIS, M., TRANOS, M., SPYROPOULOS, N., PATRAS, D., SYRIDES, G., LABRINOS, N. AND LAGGALIS, T. 1997. Neotectonic Maps of Langada and Thessaloniki, Laboratory of Geology and Paleontology, Univ. of Thessaloniki, 2 maps and 2 leaflets.

PAPAZACHOS, B.C., MOUNTRAKIS, D., PSILOVIKOS, A. AND LEVENTAKIS, G. 1979. Surface fault traces and fault plane solutions of May - June 1978 major shocks in the Thessaloniki area. Tectonophysics 53, 171183.

PAPAZACHOS, B. C. AND PAPAZACHOU, K. 1997. The earthquakes of Greece, Ziti Publ., 304pp., Thessaloniki, Greece.

PAPAZACHOS, C. B. AND KIRATZI, A. A. 1992. A formulation for reliable estimation of active crustal deformation and an application to central Greece. Geophys. J. Int. 111, 424-432.

PAPAZACHOS, C. B., KIRATZI A. A. AND PAPAZACHOS B. C. 1992. Rates of active crustal deformation in the Aegean and surrounding area. J. Geodynamics 16, $147-179$.

PAPAZACHOS, C. B., AND KIRATZI, A. A. 1996. A detailed study of the active crustal deformation in the Aegean and surrounding area, Tectonophysics 253, 129-153.

PAPAZACHOS, C., SOUPIOS, P., SAVVAIDIS, A. AND ROUMELIOTI, Z. 2000. Identification of small-scale active faults near metropolitan areas: an example from the Asvestochori fault near Thessaloniki, Proc. Of the XXVII ESC General Assembly, Lisbon, Portugal, 15-20 September 2000, (in press).

PAVLIDES, S.B. AND KILIAS, A.A. 1987. Neotectonic and active faults along the Servomacedonian zone (SE Chalkidiki, northern Greece). Annales Tectonicae 1, 9-104.

PAVLIDES, S.B., KONDOPOULOU, D.P., KILIAS, A.A. AND WESTPHAL, M. 1988. Complex rotational deformations in the Serbo-Macedonian massif (north Greece): structural and palaeomagnetic evidence. Tectonophysics 145, 329-335.

SCORDILIS, E.M., 1985. Microseismic study of the Servomacedonian zone and the surrounding area. Ph.D. Thesis, University of Thessaloniki, (in Greek). 